\title{
PEREMPUAN INDONESIA SAMPAI AWAL ABAD KE-20
}

\author{
A. Fatikhul Amin Abdullah \\ Tadris IPS, Fakultas Tarbiyah, IAIN Madura \\ f4tih85@gmail.com
}

\begin{abstract}
Abstrak
Perempuan selalu menjadi perbincangan yang menarik bagi setiap kalangan. Saat ini kadang perempuan berperan lebih dari yang dikodratkan oleh Allah Swt. Multi peran yang harus dijalani kadang membuat perempuan tidak sadar kodratnya sebagai perempuan. Di sisi lain seringkali perempuan diperlakukan tidak selayaknya sebagai makhluk yang terhormat seperti yang terjadi di Indonesia awal abad ke-20. Penelitian ini bertujuan untuk mendeskripsikan nasib perempuan Indonesia sampai awal abad ke-20. Metode yang digunakan dalam penelitian ini menggunakan metode penelitian sejarah mulai heuristik, kritik, interpretasi, dan historiografi. Hasil penelitian ini menjelaskan pandangan adat istiadat terhadap perempuan, nasib perempuan Indonesia dan lahirnya kesadaran perempuan Indonesia.
\end{abstract}

Kata kunci: Perempuan Indonesia, diskriminasi,kesadaran

\section{Abstract}

Women have always been an interesting conversation for everyone. Nowadays sometimes women play more roles than God Almighty. Multi roles that must be undertaken sometimes make women unconscious of their nature as women. On the other hand, women are often treated improperly as dignified creatures as happened in Indonesia in the early 20th century. This research aims to describe the fate of Indonesian women until the early 20th century. The method used in this study uses historical research methods from heuristics, criticism, interpretation, and historiography. The results of this study explain the views of customs towards women, the fate of Indonesian women and the birth of awareness of Indonesian women.

Keywords: Indonesian women, discrimination, awareness 


\section{PENDAHULUAN}

Agama sering dijadikan sumber legitimasi teologis yang tak terbantahkan atas kenyataan yang menyudutkan perempuan. Hal itu terus berkembang sampai masa kini karena pemahaman atas teks agama hanya secara tekstual tanpa memperhatikan konteks tempat, waktu dan budaya yang berkembang saat dalil tersebut diturunkan. Seperti yang terdapat dalam hadits rasul "tidak akan bahagia suatu kaum yang menjadikan seorang wanita menjadi pemimpin mereka" (HR Bukhari) atau ayat Al Qur-an dalam surat An-Nisa' 34 "kaum laki-laki adalah pemimpin bagi kaum perempuan, oleh karena itu Allah melebihkan sebagian mereka (laki-laki) atas sebagian yang lain (wanita)............ berdasarkan dalil tersebut seolah-olah perempuan berada pada posisi marginal.

Anggapan rendahnya posisi kaum perempuan dibanding kaum laki-laki berakibat perempuan masih tetap dalam dominasi lakilaki. Laki-laki berhak atas kehidupan kaum perempuan sehingga dengan seenaknya lakilaki berbuat tanpa memperhatikan fisik, psikis, kejiwaan, dan perasaan perempuan. Hal itu memicu aktifis perempuan membentuk suatu Lembaga Swadaya Masyarakat (LSM) yang bertujuan menjaga kehormatan dan menjamin hak-hak perempuan baik dalam ranah publik maupun domestik (rumah tangga). Beberapa LSM yang bergerak dibidang perempuan seperti Kalyanamitra (gerakan advokasi dan penanganan korban pemerkosaan), Perserikatan Kelompok Perempuan Sadar (PKPS) sebagai sarana advokasi dan penanganan korban kekerasan terhadap perempuan gereja), Perserikatan Solidaritas Perempuan (PSP) yaitu gerakan pada advokasi dan penanganan kekerasan terhadap buruh migran perempuan), Gerakan Anti Kekerasan Terhadap Perempuan di Indonesia (GAKTPI) yaitu gerakan penyadaran akan bentuk-bentuk kekerasan terhadap perempuan Indonesia, Rifka Annisa yang memfokuskan pada penanganan kekerasan perempuan dalam keluarga, Yayasan Anisa Swasti/Yasanti (fokus penanganan kekerasan terhadap buruh perempuan), Inaswati (penanganan kekarasan terhadap anak-anak perempuan jalanan), Asosiasi Perempuan Indonesia untuk Keadilan (APIK) yang kegiatannya berfokus pada advokasi dan bantuan hukum untuk korban kekerasan terhadap perempuan oleh negara dan masih banyak lagi organisasi nonpemerintah yang didirikan untuk menjaga dan menjamin hak perempuan (Murniati, 1998:22).
Perkembangan perjuangan pada akhir tahun 1990-an banyak pertemuan tingkat dunia yang membicarakan hak perempuan seperti konfrensi dunia yang berusaha menghapus diskriminasi terhadap perempuan di Wina Juni tahun 1993, di Kairo bulan September 1994, dan di Beijing tahun 1995 yang membicarakan status dan peran perempuan (Nursyahbani, 1998:vii). Selain itu banyak kaum perempuan dan juga kaum lakilaki yang tergabung dalam LSM yang peduli terhadap nasib dan kedudukan perempuan demi menanggulangi adanya kekerasan terhadap kaum perempuan seperti Komnas Perlindungan Perempuan dan Anak (KPPA) juga banyak LSM yang bertujuan membela dan menghapus diskriminasi terhadap perempuan.

Organisasi-organisasi tersebut tergabung dalam berbagai forum yang memiliki jaringan di seluruh Indonesia yang membuat gerakan demokratisasi secara sinergis. Kumpulan pengalaman kasus yang pernah ditangani organisasi-organisasi pembela perempuan dapat menjadi pelajaran bagi kita semua tentang mengapa selama ini seolah kita semua "buta, tuli, dan bisu" terhadap penderitaan sesama?. Tahun 2000an pun masih banyak didapati praktik pemonopolian kekuasaan oleh laki-laki terhadap perempuan dalam rumah tangga seperti poligami, dan berbagai jenis KDRT (Kekerasan Dalam Rumah Tangga) baik kekerasan secara ekonomi, fisik, maupun psikologis bahkan kekerasan seksual. Semua terjadi karena adanya semacam keyakinan bahwa suami boleh memperlakukan istri sekehendak sendiri karena suami memilikinya. Anggapan kepemilikan istri oleh suami ini memicu terjadinya pendiskriminasian dan penganiayaan terhadap istri yang terjadi dalam keluarga. Hal itu tampak wajar jika dipandang dari sudut pandang laki-laki, tetapi sesunguhnya merupakan penderitaan yang sangat berat apabila dilihat dari sudut pandang perempuan (Nursyahbani, 1998:24).

Penindasan dan kekerasan terhadap perempuan justru lebih banyak terjadi di rumah tempat yang selama ini dianggap paling aman bagi perempuan. Hal yang lebih menyakitkan, pelaku kekerasan umumnya adalah figur yang sangat dikenal oleh si korban (ayah, suami, paman, bahkan kakak laki-laki) sehingga perempuanpun tidak berani menolak demi menuntut haknya sebagai manusia yang merdeka. Kebudayaan Indonesia yang menganut paham patriarkhi ini berkembang menjadi struktur "agama". Dalam perkembangan budayanya, manusia membuat ajaran-ajaran, hukum, larangan, sanksi, serta 
dogma yang kemudian dinamakan agama. Bentuk hubungan yang telah menjadi struktur agama ini menjadi keras dan mati karena berproses menjadi ideologi (Murniati, 1998:22). Manusia beriman pasti berkeyakinan bahwa sang pencipta, sumber kebenaran, adalah maha baik dan maha adil, apabila dalam kehidupan manusia terjadi penyimpangan dari hal yang baik pasti itu bukan berasal dari Dia (Tuhan) demikian pula ajaran tentang relasi laki-laki dan perempuan dalam kehidupan,

Penindasan dan penyiksaan perempuan Indonesia dalam rumah tangga menjadi hal yang wajar bagi laki-laki tetapi musibah besar bagi kaum perempuan. Perempuan-perempuan Indonesia selalu dianggap sebagai suatu bagian dari kelompok manusia yang tidak bersuara, atau suaranya tak terdengar. Suara adalah syarat pertama untuk berbicara walaupun bukan satu-satunya alat komunikasi. Maka, kalau perempuan tidak bersuara (voiceless), maka hampir dengan sendirinya menjadi kelompok yang tidak berkata-kata (speechless), dan tidak pernah memberikan suaranya (the silent majority). Hal tersebut terjadi karena kuatnya budaya Patriarkhi di Indonesia yang memposisikan perempuan sebagai subordinat bagi kaum lakilaki. Perlakuan diskriminasi perempuan Indonesia sampai awal abad ke-20 dianggap sebagai pelaksanaan ajaran agama yang bersumber dari teks-teks yang suci. Padahal disisi lain agama apapun lebih-lebih Islam mengajarkan kesederajatan antara makhluk yang satu dengan yang lain. Artinya antara keadaan yang ada dan yang seharusnya terjadi kesenjangan antar keduanya. Oleh sebab itu perlu dibahas dan diteliti lebih mendalam penyebab kesenjangan antara ajaran agama dengan kenyataan yang terjadi di Indonesia dalam menyikapi peran perempuan baik di ranah domestik maupun publik.

Berdasarkan latar belakang tersebut peneltian ini fokus untuk mendeskripsikan kondisi atau potret perempuan Indonesia sampai awal abad ke-20 .

\section{METODE}

Metode penelitian yang digunakan dalam penelitian ini adalah metode penelitian sejarah. Dalam implementasinya metode penelitian sejarah terdiri dari empat tahap yaitu pertama, Heuristik (mencari sumber baik primer, sekunder maupun tersier), kedua, Kritik (menguji kebenaran atau kredibilitas sumber yang akan digunakan sebagai data penelitian), ketiga, Interpretasi (melakukan penafsiran dari berbagai data yang telah dikritik sebelumnya dengan menggunakan konsep-konsep antropologi dan tahap yang keempat, Historiografi (menyajikan hasil interpretasi data penelitian berupa tulisan atau laporan penelitian).

\section{HASIL DAN PEMBAHASAN}

\section{Pandangan Adat Istiadat Terhadap Perempuan}

Adat istiadat adalah suatu entitas yang tidak dapat dipisahkan dari peraturan yang tidak tertulis, yang berkembang seiring waktu dan perubahan dari kelompok sosial yang bersangkutan (Steurs, 2008:9). Adat Istiadat yang berlaku di masyarakat sangat dipengaruhi ajaran agama yang ada. Adanya beberapa penafsiran teks agama yang kurang sesuai memicu adanya sikap egois dari kaum laki-laki yang melahirkan beberapa kekerasan dan penindasan terhadap kaum perempuan. Kekerasan terhadap kaum perempuan ini banyak terjadi dalam rumah tangga yang pelakunya adalah orang-orang yang dekat dengan dirinya seperti: ayah, suami, paman, bahkan kakak laki-laki (Mulia:2004).

Laki-laki dan perempuan dianggap sebagai atasan dan bawahan, majikan dan pembantu. Hal ini telah ada dan jauh sebelum agama Muhammad lahir di dunia khusunya di Indonesia sampai awal abad ke-20. Perempuan dianggap sebagai makhluk yang mirip manusia dengan kata lain bukan manusia (Ridjal:1993).

Tahun 1900an dan sebelumnya perempuan Indonesia harus menerima cara hidup yang terbatas dan diisi dengan berbagai kewajiban-kewajiban untuk keluarga dan rumah tangga dengan hak yang sangat minim. Banyak ketidakadilan dalam adat istiadat yang berlaku dalam perkawinan seperti kawin paksa, sistem poligami, sistem selir ${ }^{1}$, ditambah dengan adanya sistem nyai ${ }^{2}$ dalam masyarakat kolonial.

Indonesia berpenduduk sebagian besar adalah muslim. Selain sistem dan struktur budaya asli Indonesia, banyaknya pemahaman terhadap teks agama secara tekstual juga menjadi dasar pendiskriminasian hak-hak perempuan Indonesia dalam rumah

\footnotetext{
${ }^{1}$ Istri yang dinikahi tetapi kedudukannya lebih rendah daripada istri yang utama yang disebut Padmi. Seorang selir berasal dari tingkat sosial yang lebih rendah daripada suaminya, juga kalau dibandingkan dengan Padmi. Begitu pula anak selir dianggap lebih rendah kedudukannya daripada anak Padmi

${ }^{2}$ Seorang wanita pribumi yang menjadi istri orang asing tanpa dinikah, kedudukannya sangat lemah dalam hukum, begitu pula anak-anaknya. Mereka tidak dapat menuntut apa-apa, apabila ditinggal ayahnya yang pulang ke tanah airnya, yang sering terjadi.
} 
tangga dan perkawinan. Selain itu banyak pula kitab klasik yang membahas khusus kewajiban perempuan dengan segala pembatasan dan peminggiran posisi perempuan seperti Uqud Al Lujain karya Imam Nawawi.

Kompleksitas perempuan dapat diamati dinamikanya dalam sejarah manusia, munculnya manusia selalu dibarengi kemunculan perempuan. Namun, volume pembicaraan miring tentang perempuan lebih nyaring dibanding laki-laki, misalnya dalam sejarah manusia pertama, Hawa dianggap perempuan yang menjerumuskan Adam karena digoda setan. Hingga sejarah telah mencatat bagaimana perilaku masyarakat jahiliyah terhadap bayi perempuan, mereka sampai hati mengubur hidup-hidup bayi perempuan yang tak berdosa. Perlakuan yang sama terhadap perempuan juga dirasakan di Prancis. Dua abad sebelum Islam datang sebagian mempertanyakan perempuan itu manusia apa setan?, apakah perempuan itu binatang? Mereka dianggap seperti unta dan anjing galak karena mereka adalah penangkap iblis (Nafsin dan Afiandi, 2005:9).

Di Mesir juga terjadi hal yang sama, setiap tahun dilakukan pemujaan terhadap sungai Nil dengan jalan mengorbankan gadisgadis cantik untuk dilempar ke dalam sungai Nil. Bahkan dalam perundang-undangan Romawi, wanita dipandang sebagai makhluk yang tak sempurna, sehingga hak-haknya tidak terlepas dari hak suaminya. Di negeri Yunani Kuno dan Persia, perempuan diperlakukan sebagai barang dagangan yang diperjualbelikan. Begitu pula di India kuno apabila suami mati dan jenazahnya istri harus dibakar dalam bara api dan turut terbakar bersama jenazah suaminya. Di negeri Tiongkok pun sama perempuan harus dipenjara dalam rumahnya dan apa yang datang kepadanya harus patuh dan terima. Demikian juga dalam konfucu dinyatakan bahwa ada dua jenis manusia yang suka diurus yaitu tuduhan orang rendahan dan perempuan. Sedangkan pernyataan yang diberikan tokoh logika terkenal, Aristoteles menyebutkan bahwa perempuan sebagai manusia yang belum selesai yang tertahan dalam perkembangan tingkat bawah (Nafsin dan Afiandi, 2005:12).

\section{Nasib Perempuan Indonesia}

Secara umum budaya yang dianut negeri kita adalah budaya patriarkhi. Ideologi patriarkhi merupakan salah satu variasi dari ideologi hegemoni, suatu ideologi yang membenarkan penguasaan satu kelompok terhadap kelompok lainnya. Budaya mengagung-agungkan kaum laki-laki tersebut hampir merata diseluruh Indonesia. Sistem patriarkhi di Indonesia menggejala, baik pada masyarakat yang menganut sistem keluarga patrilineal (misalnya Batak), bilateral (misalnya Jawa), maupun matrilineal (misalnya Minang).

Saadah Alim dalam buku Peranan Dan Kedudukan Perempuan Indonesia karya Maria Ulfah Subadio yang dipetik dari tulisan Saadah Alim berjudul: Minangkabau, eenige grepen uit de samenliving, dalam Indisch Vrouwenjaarboek 1936, susunan M.A.E. van lith-van schreven halaman 86 menjelaskan posisi perempuan Minangkabau yang mengikuti sistem patrilineal. Dalam buku tersebut dijelaskan tidak ada penganut poligami di tempat lain yang melebihi di Minangkabau. Perempuan Minang harus mampu menyembunyikan duka cita dan penderitaan yang ditanggungnya yakni harus membagi cinta suaminya dengan seorang madu atau lebih. Tidak hanya itu, tidak jarang terjadi bahwa istri-istri sah seorang suami bertempat tinggal hanya beberapa rumah antara satu dengan yang lain. Yang lebih mengenaskan lagi, merupakan hukum yang tak tertulis, bahwa istri pertama harus mengundang makan istri muda suaminya tak lama sesudah perkawinan mereka, sebagai tanda kesedihannya juga harus datang menjenguk bila bersalin. Jika sang istri berani menunjukkan sikap memberontak kepada suami maka dengan gampang suami akan mengeluarkan secarik kertas atau sepatah kata yang akan menjatuhkan talak padanya dan keinginan si istri sama sekali tidak diperhitungkan. Perkawinan berganda atau poligami ini dipermudah oleh adat, yang tidak mewajibkan seorang ayah mengurus anakanaknya. Karena sistem matriarkat, anak-anak termasuk keluarga si ibu, yang kepala keluarganya adalah mamak, pamannya.

Penindasan perempuan tidak hanya di Jawa dan di Minangkabau tetapi hampir di seluruh Indonesia. Hal itu seperti juga posisi perempuan Bali dalam rumah tangga. R. Van Eck menjelaskan dengan gamblang tentang nasib kaum wanita Bali sekitar tahun 1872 yang telah di muat dalam buku Peranan dan Kedudukan Perempuan Indonesia karya Maria Ulfah Subadio, yang menjelaskan tidak ada sebuah peraturan pun yang membatasi poligami dan melindungi perempuan terhadap tindakan sewenang-wenang kaum laki-laki. Ajaran yang ada di Bali seorang laki-laki boleh mempunyai istri sebanyak yang diinginkan asalkan dapat membelanjainya. Adapun ajaran kepada para istri, seorang istri harus menurut saja tanpa mengeluh dan harus 
selalu berterima kasih kepada suaminya. Apabila muncul hasrat dari sang istri untuk menyerahkan dirinya ke pangkuan laki-laki lain sebagai balas dendam kekesalan kepada suaminya maka sang suami tidak akan raguragu membunuhnya dengan keris atau akan menjualnya kepada penawar tertinggi. Selain itu, undang-undang yang ada memberi kebebasan kepada para suami untuk menyianyiakan istrinya dan juga menyerahkan sekehendaknya kepada siapa suami itu memiliki hutang dan jika istri memiliki kekurangan sedikit saja dalam melayani suami maka suami berhak menceraikannya selamalamanya. Dalam hal ini perempuan atau istri kehilangan semua hak atas anak-anaknya dan boleh pulang ke keluarganya dengan membawa $1 / 3$ bagian dari barang yang bergerak. selain itu banyak sekali terjadi penindasan atau pengebirian hak perempuan Indonesia di masa itu.

Penindasan terhadap perempuan di Indonesia sampai awal abad ke-20 dalam bentuk kawin paksa (perempuan banyak yang dikawinkan dengan suami yang belum pernah dilihatnya, atau sudah pernah dilihat tetapi belum dikenal; dalam segala hal hanya boleh bilang "ya" saja), poligami (dulu boleh dikatakan biasa saja seorang laki-laki beristri lebih dari seorang dan diam dalam satu rumah pula), kekuasaan tidak terbatas dari kaum lakilaki dalam perkawinan (seorang laki-laki dengan begitu saja sewaktu-waktu boleh menceraikan isterinya, tidak usah mengatakan sebab-sebabnya dan tidak ada beban kewajiban untuk menyokong istri yang diceraikan). (Pringgodigdo,1994:22). Selain itu juga banyak praktik pernikahan dini yang terjadi dari kalangan perempuan tanpa memperhatikan kesiapan fisik maupun psikis karena rasa gengsi orang tua memiliki anak perempuan berumur dan adat kebiasaan tetap tinggal di rumah (gadis-gadis sejak mulai menginjak waktu dewasa tidak boleh meninggalkan rumah)(Pringgodigdo, 1994:22). Laki-laki menganggap perempuan sebagai barang yang diperlakukan sekehendak hatinya. Begitulah pandangan dan perlakuan perempuan kala itu. Perempuan tak ada bedanya dengan benda mati yang tidak dapat merasakan sesuatu, selayaknya sebuah benda, setelah pengguna puas membabat habis benda tersebut maka pindahlah ia pada benda yang lain dan ia perlakukan sama benda tersebut dengan benda semula, dalam kata lain "habis manis sepah dibuang" (Nafsin dan Afiandi, 2005:9). Dalam surat kabar Poetri Hindia edisi Maret 1911 memuat suara hati perempuan Indonesia masa itu. Perempuan sangat tidak berharga di hadapan laki-laki atau suaminya dan kaum perempuan juga sangat sengsara jika diperlakukan semacam ini padahal perempuan punya perasaan yang sangat lembut. Perempuan hidup bagaikan wayang yang tidak berkuasa untuk menjalankan dirinya sendiri tanpa komando kaum laki-laki. Jika melanggar dengan mencoba berjalan sendiri tentu akan mendapat marah besar dari suami. Para suami memandang istrinya bagaikan domba, suami akan mendatangi hanya jika ada perlunya, setelah selesai mereka pun akan menerlantarkan para istri bagaikan memperlakukan bunga yang harum dan segar begitu layu, diletakkan di mana saja dan mencari yang lain. Jika suami sudah tidak cinta lagi pada istrinya, laki-laki itu sekehendak hati meninggalkan istrinya (bahkan menceraikannya) dan mencari perempuan lain, minuman keras, berjudi dan sebagainya tanpa mempedulikan kebutuhan lahir dan batin istrinya.

Perempuan yang berani mengingatkan, tidak akan diterimanya tetapi yang didapat malah kemarahan dari suami. Perlakuan sewenang-wenang pihak suami terhadap istrinya dalam hal ini dianggap sebagai suatu kewajaran dan tak akan ada satu pun dari orang lain akan membela kaum perempuan untuk lepas dari kungkungan keadaan yang semacam itu.

\section{Persepsi Laki-Laki Terhadap Perempuan}

Imajinasi orang jawa, memandang lelaki ideal adalah yang memiliki benggol (uang) dan bonggol (kejantanan seksual). Dalam hal ini perempuan adalah milik laki-laki, sejajar dengan bondo (harta), griyo (istana), turonggo (kendaraan), kukilo (burung, binatang piaraan, bunyi-bunyian), dan pusoko (senjata, kesaktian). Penguasaan terhadap perempuan (wanito) adalah simbol kejantanan seorang laki-laki. Sebaliknya, pada perempuan tidak ada independensi. Ketundukan, ketergantungan, dan kepasrahan perempuan atas laki-laki adalah gambaran kemuliaan hati seorang perempuan Jawa (Darwin, 2001:23).

Secara psikologis semua laki-laki merasa bangga dengan memiliki istri banyak. Naluri semua laki-laki memiliki potensi untuk melakukan poligami. Laki-laki merasa puas dengan mampu menikmati tubuh-tubuh perempuan yang identik dengan keindahannya. Oleh sebab itu, "agama" memberikan peluang akan hal itu. Berbeda dengan perempuan, mereka secara psikologis tidak memiliki hasrat untuk melakukan poliandri walaupun secara kemampuan dia mampu. Karena sesungguhnya perempuan lebih mengedepankan perasaan ingin dicintai 
dan dimiliki secara utuh oleh sosok laki-laki (suami). Jadi bagi perempuan cinta suami adalah segala-galanya sedangkan bagi lakilaki badan perempuanlah yang menentukan kebahagiaannya (Hakeem:2005). Oleh sebab itu sangat menyakitkan bagi perempuan (istri) jika suaminya melakukan poligami, tetapi bagi laki-laki adalah hal yang biasa.

Artikel lain yang ditulis oleh Siti Ramalah dalam soerat kabar Poetri Hindia edisi Januari 1910 dengan gamblang sekali membeberkan penderitaan yang dialami oleh kaum perempuan baik sebagai anak perempuan, Istri, bahkan telah jadi lbu sekalipun.

Siti Ramalah menuturkan dengan lantang dan berani dalam bahasa tulis tentang nasib perempuan waktu itu, tentu ini menjadi jeritan hati kaum perempuan yang sudah tidak kuat lagi melihat sebagian besar saudaranya ditindas, dinista, dianiaya bahkan dicampakkan begitu saja tanpa rasa peri kemanusiaan. Perempuan diumpamakan bagai binatang, bisa dibayangkan penderitaan kaum perempuan hingga Siti Ramalah dengan menggunakan istilah "koeda beban" untuk menyebut kaum perempuan masa itu karena kesengsaraan yang luar biasa.

Umur sembilan tahun merupakan umur yang sangat belia dan tergolong anakanak tetapi sudah dibebani tangung jawab yang sangat besar untuk masuk dalam bahtera rumah tangga yang didalamnya terdapat berjuta permasalahan yang membutuhkan kematangan berfikir, kesiapan fisik, dan kedalaman pengetahuan, serta kesabaran untuk mengatasinya. Perasaan perempuan sudah tidak ada harganya lagi bahkan dianggap perempuan makhluk tak punya rasa hingga dengan seenaknya orang tua memaksa untuk mengawini laki-laki yang tanpa ada rasa cinta sama sekali dan belum tahu siapa laki-laki yang akan menjadi pendamping hidupnya. Asal bapak senang itulah prinsip pernikahan yang terjadi sekitar tahun 1910-an karena anak perempuan tiada kuasa untuk menolak kehendak orang tua walaupun hati menjalani dengan keterpaksaan.

Pernikahan dini dalam kaca mata kesehatan sangatlah berbahaya karena mengakibatkan munculnya penyakit kanker mulut rahim, selain itu kelahiran dari ibu yang terlalu muda akan mengakibatkan anak yang dilahirkan memilki kelambatan dalam berfikir karena secara medis sel yang dibuahi belum matang secara total. Dari sisi ibu yang melahirkan pun sangat berbahaya karena perkembangan alat reproduksinya belum sempurna sehingga banyak terjadi kematian saat melahirkan (Blackburn:2005)

Penderitaan kaum perempuan akan lebih berat jika telah menyandang status sebagai Bini (istri) karena jika suami sudah tidak lagi suka atau cinta kepadanya suami akan berbuat seenaknya sendiri. Perempuan dengan mudahnya diceraikan oleh suami atau disakiti walau ia (istri) telah menaruh hati kepadanya. Jika si istri tak suka tetapi suaminya cinta kepadanya si istri tidak akan mampu melepas tali perkawinan tersebut. Perempuan (istri) tidak memiliki hak untuk melepaskan diri dari tali perkawinan. Nasib istri yang enggan untuk melayani suami karena memang tidak cinta maka penderitaan istripun semakin berat karena istri dinusyuskan oleh suami (diterlantarkan).

Saat perempuan (istri) meminta cerai sedangkan suami tidak mau memberi talak suami bisa meminta ongkos yang sangat besar sebagai penebus dirinya dan jika kebetulan suaminya nakal, istri tidak akan dicerai sebelum istri membayar sampai tiga kali. Nasib istri yang mendapat laki-laki pemalas, pemadat, yang hanya memikirkan enaknya sendiri si istri dipekerjakan seperti benar-benar kuda beban yang disuruh bekerja cari penghidupan apabila pulang tanpa membawa uang dia akan dicaci-maki bahkan akan ditampar karena tidak membawa apa yang disukai suaminya (madat).

\section{Lahirnya Kesadaran Perempuan Indonesia}

Banyaknya kekerasan yang diterima kaum perempuan oleh kaum laki-laki awal abad ke-20 sungguh sangat memprihatinkan dan cukup menjadi suatu alasan untuk menggalang kekuatan dalam merubah adat yang telah lama berakar pada kebudayaan jawa. Praktik pernikahan dini, kawin paksa, perceraian sewenang-wenang secara sepihak dari kaum laki-laki, dan kekerasan dalam rumah tangga sungguh sudah tidak dapat dibiarkan. Hal ini menjadi faktor pendorong perempuan untuk melakukan gerakan sosial sebagai upaya mengentaskan diri dari kubangan budaya dan kebiasaan yang merugikan tersebut.

Indonesia memiliki pahlawan perempuan yang sampai sekarang harum namanya. Beliau berusaha keras menuntut persamaan hak perempuan bumi putra yang terkungkung dalam adat istiadat yang sangat merugikan kaum perempuan, dialah R.A Kartini (1879-1904) (Chodijah, 1986:16), seorang putri Adipati Jepara yang menentang adat pingitan bagi anak perempuan. Kartini dikenal karena banyaknya koleksi surat yang 
ditulis sebagai bentuk curahan hati gadis bumi putera kepada J.H Abendanon.

Penindasan dan penyiksaan perempuan Indonesia dalam rumah tangga menjadi hal yang wajar bagi laki-laki tetapi musibah besar bagi kaum perempuan. R.A Kartini menuliskan nasib perempuan Indonesia dalam suratnya yang dikirimkan kepada nyonya Abendanoon ${ }^{3}$ bulan Agustus 1900 berikut kutipannya

"Saudaraku si kulit putih yang sangat pengasih penyayang, yang luas pemandangan, yang berpikir tajam, tolonglah kami, angkatlah kami daripada lumpur derita sengsara ini, tempat kami didorong dibenamkan oleh loba laki-laki. Tolonglah kami, melawan loba laki-laki yang ganas, yang semata-mata memikirkan dirinya sendiri itu, sifat loba iblis yang sepanjang masa mengazab menindas perempuan, sehingga, karena biasa disiksa, tiadalah lagi memandang siksaan itu lalim, melainkan menerimanya dengan hati tunduk dan tawakkal, memandangnya jadi hak lakilaki, yang sesungguhnya, jadi pusaka, penderitaan setiap perempuan. Benar, aku masih muda, tetapi aku tiada buta dan tiada tuli, dan banyaklah sudah yang kulihat dan yang kudengar, bahkan sudah terlalu banyak, sehingga hatiku hancur karena sedihnya, sehingga dicambuknya hatiku supaya aku tegak berdiri melawan adat, kebiasaan yang jadi kutuk bagi perempuan dan anak-anak!" (Pane, 2006:55).

Surat-surat Kartini yang ditulis pada tanggal 25 Mei 1899 kepada Stella Zeehandelaar ${ }^{4}$, seorang gadis Belanda sebagai jeritan batin yang menggambarkan nasib perempuan waktu itu inilah penggalan kutipan surat Kartini:

" Kami, gadis-gadis masih terantai kepada adat Istiadat lama, hanya sedikitlah memperoleh bahagia dari kemajuan pengajaran itu. Kami anak perempuan pergi belajar ke sekolah, keluar rumah tiap-tiap hari, demikian itu saja sudah dikatakan amat melanggar adat. Ketahuilah, bahwa adat negeri kami melarang keras gadis keluar rumah. Ketika saya sudah berumur dua belas tahun, lalu saya ditahan di rumah saya mesti masuk "tutupan"; saya dikurung di dalam rumah seorang diri, sunyi senyap terasing dari dunia luar. Saya tiada boleh keluar ke dunia itu lagi, bila tiada serta seorang suami, seorang laki-laki yang asing sama sekali bagi kami, dipilih oleh orang tua kami untuk kami, dikawinkan dengan kami,

\footnotetext{
${ }^{3}$ Istri Mr. Abendanon yang pernah menjadi directeur Departemen Onderwijs, eredienst en Nijverheid. Beliau disebut oleh Kartini lbu.

${ }^{4}$ Istri tuan Harsthalt, beliau belum pernah bertemu dengan R.A. Kartini; Cuma berkenalan dengan surat saja.
}

sebenarnya dengan tiada setahu
kami..........." (Pane, 2006:35).

Surat ini membenarkan deskripsi yang diberikan B.H. Lans kepala sekolah dari Belanda yang datang ke Indonesia pada tahun 1913 ia membagi masa kehidupan perempuan Sunda (tempatnya bekerja) menjadi tiga periode masa kanak-kanak, masa penuh kepatuhan sebagai istri dan ibu, dan masa dengan pengaruh besar sebagai nenek (Steurs, 2008:62).

Perjuangan Kartini mampu menyadarkan perempuan Indonesia akan posisi, hak, kewajiban, dan peran yang sebenarnya sebagai anak perempuan, istri, ibu, dan nenek. Dalam surat kabar Poetri Mardika edisi Juli 1915 memuat artikel yang berjudul "Adat Jang Haroes Kita Linjapkan" menjelaskan masih banyaknya praktik pernikahan dini di masyarakat karena orang tua merasa malu jika memiliki anak perempuan yang berumur 12 tahun belum juga mendapat suami. Orang tua berupaya keras mencarikan laki-laki yang mau menikahi anak perempuannya tanpa meminta pesetujuan anak perempuannya bersedia atau tidak. Ketika pihak laki-laki telah setuju dan mau menikah dengan putrinya, orang tua tak sepatah katapun meminta persetujuan putrinya untuk kawin dengan lelaki pilihannya itu karena berfikir cinta orang perempuan akan tumbuh dengan berjalannya waktu.

$$
\text { Perkawinan merupakan awal }
$$

kesengsaraan bagi kaum perempuan Indonesia. Dalam surat kartini yang dikirimkan kepada nona Zeehandelaar pada tanggal 25 Mei 1899 menggambarkan kawin adalah azab, berikut kutipan surat Kartini:

$$
\text { "Dan kawin disini, aduh, }
$$

dinamakan azab sengsara masih terlalu halus! Betapa nikah itu tiada akan sengsara, kalau hak semuanya bagi keperluan laki-laki saja dan tiada sedikit juapun bagi perempuan? Kalau hak dan pengajaran kedua-duanya bagi laki-laki semata-kalau semua-muanya dibolehkan dia perbuat?

Cinta, apakah yang kami ketahui tentang perkara cinta itu? Betapa kami akan mungkin sayang akan seorang laki-laki dan seorang laki-laki kasih akan kami, kalau kami tiada berkenalan bahkan yang seorang tiada boleh melihat yang lain? Anak gadis dan anak muda dipisahkan benarbenar.........." (Pane, 2006:36).

Hal ini yang menjadikan kehidupan perempuan dalam rumah tangga bagai tidak ada harganya dan hak perempuan sudah tidak diperhatikan karena istri tidak kenal kepada suaminya sendiri. 


\section{PENUTUP}

\section{Simpulan}

Perempuan Indonesia sebelum abad ke-20 banyak mengalami diskriminasi dari kaum lakilaki yang ada di sekitarnya. Seringkali diskriminasi tersebut dilakukan oleh orangorang terdekatnya seperti ayah, suami, atau kakak laki-lakinya. Diskriminasi tersebut disebabkan karena kesalahan dalam menafsirkan teks-teks suci baik itu Al Quran atau Hadits Nabi. Seringkali penafsiran dilakukan secara tekstual tanpa melibatkan konteks waktu dan tempat serta budaya sekitar yang ada. Hal ini dipicu juga dengan kentalnya budaya Patriarkhi yang berlaku di Indonesia dan persepsi yang salah terhadap perempuan. Laki-laki dan perempuan bagaikan atasan dan bawahan sehingga perempuan harus menerima cara hidup yang terbatas dan diisi dengan berbagai kewajiban rumah tangga dengan hak yang sangat minim. Praktik perkawinan dini, kawin paksa, praktik poligami menjadi hal yang wajar dan merata. Selain itu status Istri bukanlah status yang didambakan bagi perempuan waktu itu karena status istri menjadi awal dari penderitaan kehidupan di dunia. Perempuan diperlakukan seperti binatang yang diperlakukan pemiliknya tanpa nilai tawar. perempuan berumur sembilan dipaksa harus sudah menikah dan dibebani tanggung jawab besar masuk dalam bahtera rumah tangga dengan berjuta permasalahan rumah tangga dengan tanpa kematangan berfikir, fisik dan pengetahuan. Padahal hal ini sangat berisiko terhadap kesehatan seorang ibu. Belum juga perlakuan yang sewenang-wenang laki-laki tanpa mempertimbangkan perasaan istri. Berbagai penderitaan dan penindasan serta diskriminasi tersebut memunculkan tokoh Kartini sebagai pelopor gerakan perempuan untuk bangkit dan keluar dari kubangan diskriminasi dengan berbagai suratnya kepada sahabatnya Abendanoon.

\section{Saran}

Penelitian ini menjadi awal gambaran terdapat hal yang salah dalam memperlakukan perempuan yang seharusnya perempuan ditempatkan di tempat yang paling mulia. Oleh sebab itu, berangkat dari penelitian ini diharapkan banyak penelitian muncul membahas upaya perempuan untuk keluar dari diskriminasi dan mendapat peran yang seharusnya dalam kehidupan rumah tangga atau bahkan di ranah publik.

\author{
DAFTAR PUSTAKA \\ Arsip-Arsip \\ Verslaag Congress Perempuan Indonesia \\ $1928 \mathrm{D} / 49$ \\ Verslaag Sarikat Islam Jakarta 1931 D/30 \\ Poetri Hindia (Soerat Kabar dan \\ Advertentie Boeat Perempuan Hindia) \\ Juli 1909 \\ Januari 1910 \\ Januari 1911 \\ Maart 1911 \\ Poetri Merdika, \\ Februari 1917 \\ Desember 1916 \\ Juli 1915 \\ Novenber 1915 \\ Mei 1917 \\ Isteri \\ Agustus 1931 \\ Oktober-November 1931 \\ Juli 1932 \\ Estri Oetomo 15 Maret 1918
}

\section{Buku-buku}

Al Maliki, Sayyid Muhammad 'Alawi bin Abbas. 2004. .Adab Al Islam fi Nidhom Al Usroh. Makkah: Maktab Maliki.

Al Nawawi, Muhammad bin Umar. 1973. .'Uqud Al Lujain fi Bayani Huquq Al Zaujain. Indonesia (Tanpa kota): Syirkah Al Nur Aasiya.

Blackburn, Susan. 2007. Kongres Perempuan Pertama. Jakarta: Obor Indonesia dan KITLV.

Chodijah, Idjah. 1986. Rintihan Kartini. Jakarta: Ikhwan

Darwin, Muhajir. 2001. Maskulinitas; Posisi Laki-Laki Dalam Masyarakat Patriarkhis. dalam Menggugat Budaya Patriarkhi. Yogyakarta. Gajah Mada University Press.

Feillard, Andree. 1999. NU Vis-a-Vis Negara. Yogyakarta: LkiS,

Hadiz, Liza. 2004. Perempuan dalam Wacana Politik Orde Baru. Jakarta: LP3ES.

Hemas, Gusti Kanjeng Ratu. 1992. Wanita Indonesia Suatu Konsepsi dan Obsesi. Yogyakarta: Liberty.

Kasdi, Aminuddin. 2005. Memahami Sejarah. Surabaya: Unesa University Press.

Katjasungkana, Nursyahbani. 1998. Kata Pengantar dalam Perisai Perempuan. LBH APIK. Jakarta. 
Kuntowijoyo. Metodologi Sejarah. 2003 Yogyakarta: Tiara Wacana Yoga,

KWI. 1978. Sejarah Setengah Abad Kesatuan Pergerakan Wanita Indonesia. Jakarta: Balai Pustaka.

KWI. 1978. Sejarah Setengah Abad Pergerakan Perempuan Indonesia. Jakarta: Balai Pustaka.

Lev, Daniel S. 1986. Peradilan Agama Islam di Indonesia. Jakarta: Intermasa.

Majelis Ulama Indonesia. 1986 Tuntunan Perkawinan Bagi Ummat Islam Indonesia.Jakarta: Sekretariat MUI.

Mirsel, Robert. 2004. Teori Pergerakan Sosial. Yogyakarta: Resist Book.

Muhammad, Husein. 2004 Islam Agama Ramah Perempuan.Yogyakarta: LKiS,

Mulia, Siti Musdah. 2004. Islam Menggugat Poligami. Jakarta: Gramedia,

Murniati, A. Nunuk Prasetyo. 1998 Gerakan Anti Kekerasan Terhadap Perempuan. Kanisius Jakarta.

Nafsin, Abdul Karim dan Mifta Lidya Afiandani. 2005. Perempuan Sutradara Kehidupan di Tangan Dia Masa Depan Dunia. Mojokerto: CV. AI Hikmah.

Ohorella. G.A. dkk. 1992. Peranan Wanita Indonesia dalam Masa Pergerakan Nasional. Jakarta: Depdikbud.

Pane, Armijn. 2006. Habis Gelap Terbitlah Terang. Jakarta: Balai Putaka.

Pringgodigdo SH, A.K. 1994. Sejarah Pergerakan Rakyat Indonesia. Jakarta: Dian Rakyat.

Ridjal, Fauzi Dkk. 1993 Dinamika Gerakan Perempuan di Indonesia. Yogyakarta: PT Tiara Wacana.

Soenyono. 2005. Teori-Teori Gerakan Sosial.Surabaya: Kampusina.

Soewito, Hadi. 1995. Wanita Pejuang dalam Kancah Revolusi 45. Jakarta: Gramedia Widiasarana Indonesia.

Soewondo, Nani. 1984. Kedudukan Wanita Indonesia dalam Hukum dan Masyarakat. Jakarta: Ghalia Indonesia.

Steurs, Cora Vreede-De. 2008. Sejarah Perempuan Indonesia: gerakan dan pencapaian. Jakarta: Komunitas Bambu.

Subadio dkk. 1983. Peranan dan Kedudukan Perempuan Indonesia.Yogyakarta: Gajah Mada Press.

Sudewa, 1991. Serat Paniti Sastra, Tradisi, Resepsi, dan Transformasi Jogjakarta: ILDEP/Duta wacana Universirty Press.

Suryochondro, Sukanti. 1984. Potret Pergerakan Wanita di Indonesia. Jakarta: Rajawali. 
A.Fatikhul Amin Abdullah 